\title{
A comparison of a novel formulation of rigid polyurethane foams synthesis by hydrocarbon blowing agents
}

Zahir Bakiri ( $\square$ zahir.bakiri@univ-constantine3.dz ) Universite de Constantine 3 https://orcid.org/0000-0001-9749-2977

\section{Research Article}

Keywords: hydrocarbon blowing agents, mechanical stress, polyurethanes, thermal properties, environmental blends.

Posted Date: May 10th, 2021

DOl: https://doi.org/10.21203/rs.3.rs-481242/v1

License: (c) (i) This work is licensed under a Creative Commons Attribution 4.0 International License. Read Full License 


\section{Abstract}

A simple formulation of rigid polyurethane foams (RPUFs) is presented for obtaining a material, with good thermal insulation and long-term stability, based on the different hydrocarbon blowing agents (HBAs). The obtained formulation is prepared from isocyanate and polyol for construction application or appliances. A method and a particular experimental approach have realized to replace hazardous blowing agents (chlorofluorocarbons (CFCs) and hydrochlorofluorocarbons (HCFCs)) with other less harmful agents to improve the thermal resistance of this polymer. The obtained results are very encouraging in certain foams prepared from HBA and provide excellent performance.

\section{Introduction}

The rigid polyurethane foam (RPUF) market studies various parameters such as raw materials and their costs, injection and molding technology and their performance. RPUFs are applied in many thermal insulation products such as buildings and construction, pipe insulation, industry applications, refrigerators, freezers, refrigerated trucks, refrigerated containers, food cold storages, packaging, automotive, chemical and petrochemical industry, water heaters [1-5]. It should be noted that RPUF are the most common popular insulating materials, the most energy-efficient and multi-functional in industry $[4,6,7]$. The term polyurethane is an organic polymer composed of urethane function in its structure (also called carbamate).

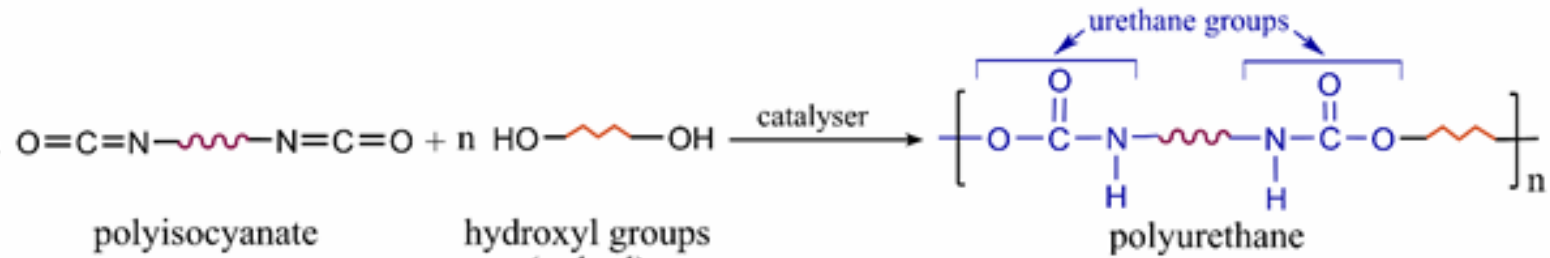

(polyol)

Polyurethane foams are a formed by the exothermic chemical reaction of a polyisocyanate with hydroxyl groups in the presence of blowing agents [7-11]. When reacting these reagents in stoichiometric quantities, these molecules can form linear polymers. Blowing agents are chemical compounds used in the production of polyurethane, which was expanded by the introduction of gas bubbles form in a liquid [12,13], which has a low boiling point is higher than the room temperature (between 20 or $25^{\circ} \mathrm{C}$ ) to avoid its evaporation during the foaming process [14]. There is also a variety of generations of physical blowing agents which are: chlorofluorocarbons (CFCs), hydrochlorofluorocarbons (HCFCs), hydrofluorocarbons (HFCs), hydrofluoroolefins (HFOs), liquid $\mathrm{CO}_{2}$, dimethoxymethane (methylal), hydrofluoro-olefins (HFO) and hydrocarbon blowing agents (HBAs) [11,15-19].

For over half a century, CFCs have been most used physical blowing agents in the polyurethane foam industry. The efficiency physical blowing agent to manufacture flexible and rigid foams was trichloromonofluoromethanes $\left(\mathrm{CCl}_{3} \mathrm{~F}\right)$, also known as Freon 11 (CFC-11). However, they were also banned from industrial usage by the Montreal Protocol in 1987 because of their ozone depletion potential (ODP) 
$[2,4,20-23]$. As well as the diffusion of CFCs and HCFCs into the stratosphere of the ozone layer in which they decompose to release chlorine atoms that would catalytically destroy ozone [12].

HFCs have been one of the principal contenders for third generation blowing agents. But their use was restricted in industry, because of their global warming potential (GWP) and the cost of sale. HBAs are considered $3^{\text {rd }}$ generation blowing agents. It should have been noted that RPUFs prepared with HBAs are the most popular to provide excellent performance, energy-efficiency, and versatile insulation materials in the construction industry $[4,21,24,25]$. These HBAs have zero OPD and almost zero GWP for hexane derivatives $[2,8,24]$. However, $4^{\text {th }}$ generation agents, such as methylal and HFO, have encouraging thermal and mechanical properties with zero ODP and low GWP. Despite these advantages, $4^{\text {th }}$ generation blowing agents have not yet found a special place in the RPUF market because of their price (more than $30 \%$ in the formulation) [26] and a high demolding time (gel/time).

The presented work was aimed to investigate the chemical formulation of rigid polyurethane foam (RPUF) used in thermal insulation and whose main objective is to compare several HBAs of pentane derivatives (n-pentane, isopentane and cyclopentane) and hexane derivatives ( $\mathrm{n}$-hexane and cyclohexane). In a first step, the RPUF preparation formula using hydrocarbon blowing agents (HBAs) is particularly detailed. Then, the experimental data that are essential to the comprehension of the reaction mechanisms and the concept of microstructure between isocyanates and polyols were presented. As well as the effect of the reactivity of the polymerization reaction, the proportion of polyol/isocyanate, the hydrocarbon blowing agents, and the synthesis process, were studied.

\section{Materials And Methods}

\section{Materials}

The different materials used in this study were obtained from commercial sources. The isocyanate and polyol are supplied from Wanhua Chemical Group (China). The isocyanate is also known as the trade name of WANNATE®PM-200, it is a polymethylene diphenyl diisocyanate (PMDI) which has -NCO groups with a functionality of about 2.65. The polyol is under the trade name WANEFOAM $B R C P 6150-101$ series and is designed to use with a hydrocarbon blowing agent (HBA). The most important physicochemical parameters of isocyanate and polyol are presented in Table 1.

Table 1. Proprieties of Polyol and PMDI. 


\begin{tabular}{|c|c|c|c|}
\hline Specifications & Appearance & $\begin{array}{l}\text { Density } \\
\text { at } 25^{\circ} \mathrm{C}\end{array}$ & $\begin{array}{l}\text { Viscosity } \\
\text { (mPa.s) } \\
\text { at } 25^{\circ} \mathrm{C}\end{array}$ \\
\hline $\begin{array}{l}\text { WANEFOAM@RCP6150-101 (PMDI) } \\
\text { NCO-content (wt \%): } 32.1 \pm 0.1 \\
\text { Acid content (wt \%): } \leq 0.05 \\
\text { Hydrolysable chlorine (wt \%): } \leq 0.2\end{array}$ & $\begin{array}{c}\text { Pale yellow } \\
\text { liquid }\end{array}$ & $1.08 \pm 0.05$ & $4000 \pm 600$ \\
\hline $\begin{array}{l}\text { WANNATE } @ P M-200 \text { (Polyol) } \\
\text { Hydroxyl-number (mg KOH/g): } 270 \pm \\
20 \\
\text { Water content (wt \%): } 2.35 \pm 1.2\end{array}$ & $\begin{array}{c}\text { Dark brown } \\
\text { liquid }\end{array}$ & $\begin{array}{c}1.235 \pm \\
0.015\end{array}$ & $200 \pm 50$ \\
\hline
\end{tabular}

Data from suppliers

To prepare a high-performance polyurethane rigid foam and excellent thermal properties, we studied five physical blowing agents that are: $n$-pentane $(n-P)$, isopentane (i-P), cyclopentane (c-P), n-hexane $(n-H)$ and cyclohexane $(\mathrm{c}-\mathrm{H})$. All these reagents provided by VWR Chemicals, Biochem Chemopharma and Aldrich. The HBAs examined are shown in Table 2. 
Table 2. Physical properties of the principal hydrocarbon blowing agents (HBAs).

\begin{tabular}{|c|c|c|c|c|}
\hline Specifications & Structure & $\begin{array}{c}\text { Gas conductivity } \lambda \\
(\mathrm{mW} / \mathrm{m} \cdot \mathrm{K}) \text { at } 25^{\circ} \mathrm{C} \\
{[8,27-30]}\end{array}$ & $\begin{array}{c}\text { ODP } \\
{[18,31]}\end{array}$ & $\begin{array}{c}\text { GWP } \\
{[18,31]}\end{array}$ \\
\hline $\begin{array}{l}\text { n-pentane }(\mathrm{n}-\mathrm{P}) \\
\mathrm{C}_{5} \mathrm{H}_{12} \\
\text { MW: } 72.15 \mathrm{~g} / \mathrm{mol} \\
\text { b.p.: } 36^{\circ} \mathrm{C}\end{array}$ & & 13.5 & 0 & 11 \\
\hline $\begin{array}{l}\text { isopentane (i-P) } \\
\mathrm{C}_{5} \mathrm{H}_{12} \\
\mathrm{MW}: 72.15 \mathrm{~g} / \mathrm{mol} \\
\text { b.p.: } 28^{\circ} \mathrm{C}\end{array}$ & & 13 & 0 & 11 \\
\hline $\begin{array}{l}\text { cyclopentane (c-P) } \\
\mathrm{C}_{5} \mathrm{H}_{10} \\
\text { MW: } 70.15 \mathrm{~g} / \mathrm{mol} \\
\text { b.p.: } 49^{\circ} \mathrm{C}\end{array}$ & & 15 & 0 & 11 \\
\hline $\begin{array}{l}\mathrm{n} \text {-hexane }(\mathrm{n}-\mathrm{H}) \\
\mathrm{C}_{6} \mathrm{H}_{14} \\
\text { MW: } 86.18 \mathrm{~g} / \mathrm{mol} \\
\text { b.p.: } 68^{\circ} \mathrm{C}\end{array}$ & & 119 & 0 & 0 \\
\hline $\begin{array}{l}\text { cyclohexane }(\mathrm{c}-\mathrm{H}) \\
\mathrm{C}_{6} \mathrm{H}_{12} \\
\text { MW: } 84.16 \mathrm{~g} / \mathrm{mol} \\
\text { b.p.: } 80.75^{\circ} \mathrm{C}\end{array}$ & & 117 & 0 & 0 \\
\hline
\end{tabular}

MW: molecular weight b.p.: boiling point

The thermal insulation factor is one of the main parameters that concern customers with energy consumption and comfort while intergovernmental organization focused on environmental protection. Table 2 shows two important observations: pentane derivatives have a very high thermal resistance (low thermal conductivity), while hexane derivatives have zero ODP and zero GWP. Therefore, the thermal insulation/environmental sustainability relationship plays a very interesting role in the choice of the blowing agent.

\section{Methods}


The materials, presented in Tables 1 and 2, necessary for the polymerization reaction must be at an operating temperature of $20 \pm 1^{\circ} \mathrm{C}$. The preparation of rigid polyurethane foam (RPUF) a process in two essential steps: (i) the polyol (Pol) is mixed with a hydrocarbon blowing agent (Pol/HBA premix) using well-defined amounts in a $500 \mathrm{ml}$ plastic cup. The mixture is stirred by hand to obtain a homogeneous mixture; and (ii) quickly add the isocyanate to the premix and use precise proportions to determine the ratio between the three components. This final mixture was mixed with a mechanical agitator for 5 to 7 seconds. After rigorous mixing, the mixture is rapidly poured into a cylindrical mold $(\varnothing 170 \mathrm{~mm} \times \mathrm{H} 350$ $\mathrm{mm}$ ) equipped with a temperature sensor and a graduated ruler for measuring the foam rise height. Then after few seconds, a change in the color of the foam is observed, which was followed by a considerable expansion of the polyurethane foam with the formation of gas bubbles. Fig. 1 shows the different steps used for the preparation and control of the foaming process.

The reactivity of the polymerization reaction of polyurethanes is measured, which is characterized by three regimes [10,27]: (i) cream time (CT) is the moment when the foam begins to rise, and bubbles start to form; (ii) string (gel) time (GT) is the moment when the foam begins to have fibres; (iii) tack-free time (TFT) is the moment at which the foam's surface becomes hard and non-sticky.

\section{Characterizations}

Many techniques are used for the analysis and characterization of RPUF. It is necessary to determine several key parameters that must be measured during processing RPUF. The samples are cutting with small parts $\left(30 \times 30 \times 30 \mathrm{~mm}^{3}\right)$ of comparable size and location for testing density, thermal conductivity, shrinkage, and stress-strain.

- The rise-core density of RPUF was cut and weighed compared by their volume.

- The thermal conductivity $(\lambda)$ of the RPUF samples was examined by using Eko Instruments (HC-074 heat flow meter).

- The shrinkage factor indicates the percentage of deformation, which measured introducing the RPUF samples in a closed vessel at 2 bars for 30 minutes. Then, the volumes of the foams are measured before and after deformation.

These tests were carried out in accordance with ASTM standards. The different characterization methods will be detailed in the results and discussion section.

\section{Formulation}

To effectively manage the development of the experiments carried out on the polymerization reaction of RPUFs, we have set up a specific schedule that brings together the various parameters influencing the formulation of this material. From these formulations, we have realized many manipulations using five different hydrocarbon blowing agents: $n-P, i-P, c-P, n-H$ and c-H. We are also studying the reactivity of the reaction of RPUF to control their parameters such as temperature, ratio, mold rise height and formation kinetics. 
The ratio determines the content of the active NCO function of the isocyanate in proportion to the total hydroxide number $(\mathrm{OH})$ of the polyol. The detailed equation of the examined ratio is given in Table 3 .

Table 3. Rigid polyurethane foams (RPUF) formulation and experimentally measured physical proprieties of the materials using different hydrocarbon blowing agents (HBAs).

\begin{tabular}{|c|c|c|c|c|c|c|c|c|c|c|}
\hline \multicolumn{11}{|c|}{ Formulation } \\
\hline Raw materials & Specifications & & & & Proc & essing (1 & t \%) & & & \\
\hline Polyol & $\mathrm{KOH} / \mathrm{g})$ & 100 & 100 & 100 & 100 & 100 & 100 & 100 & 100 & 100 \\
\hline PMDI & $\begin{array}{l}31 \pm 1 \quad(\% \\
\text { NCO- No) }\end{array}$ & 130 & 140 & 150 & 130 & 140 & 150 & 130 & 140 & 150 \\
\hline & $n-P$ & 12 & 13 & 14 & 13 & 14 & 12 & 14 & 12 & 13 \\
\hline & $i-P$ & 12 & 13 & 14 & 13 & 14 & 12 & 14 & 12 & 13 \\
\hline HBAs & $c-P$ & 12 & 13 & 14 & 13 & 14 & 12 & 14 & 12 & 13 \\
\hline & $n-H$ & 12 & 13 & 14 & 13 & 14 & 12 & 14 & 12 & 13 \\
\hline & $\mathrm{c}-\mathrm{H}$ & 12 & 13 & 14 & 13 & 14 & 12 & 14 & 12 & 13 \\
\hline Mixing ratio & $\frac{\mathrm{PMDI}}{\mathrm{Pol}+\mathrm{HBA}}(w t \%)$ & 1.161 & 1.239 & 1.316 & 1.150 & 1.228 & 1.339 & 1.140 & 1.250 & 1.324 \\
\hline
\end{tabular}

Foaming characteristics and physical properties

\begin{tabular}{|c|c|c|c|c|c|c|c|c|c|c|}
\hline $\begin{array}{l}\text { Maximum } \\
\text { Height* }\end{array}$ & $(\mathrm{mm})$ & 272 & 284 & 296 & 289 & 302 & 268 & 295 & 273 & 291 \\
\hline $\begin{array}{l}\text { Maximum } \\
\text { temperature* }\end{array}$ & $\left({ }^{\circ} \mathrm{C}\right)$ & 136.5 & 138.2 & 138.7 & 136.0 & 138.0 & 141.8 & 135.8 & 139.2 & 140.0 \\
\hline \multirow{5}{*}{$\begin{array}{l}\text { RPUF free- } \\
\text { rise density }\end{array}$} & $n-P$ & 25.5 & 24.7 & 23.4 & 24.5 & 23.2 & 26.1 & 23.5 & 25.1 & 24.8 \\
\hline & $\mathrm{i}-\mathrm{P}$ & 25.0 & 24.5 & 23.6 & 24.4 & 23.8 & 25.7 & 23.3 & 25.0 & 24.8 \\
\hline & $c-P \quad\left(K g / m^{3}\right)$ & 25.2 & 24.3 & 22.9 & 24.4 & 23.2 & 25.5 & 23.4 & 25.5 & 24.5 \\
\hline & $n-H$ & 38.4 & 37.2 & 35.9 & 37.8 & 36.3 & 38.0 & 34.5 & 38.0 & 36.5 \\
\hline & $\mathrm{c}-\mathrm{H}$ & 35.1 & 33.8 & 33.1 & 34.2 & 34.0 & 36.2 & 33.8 & 34.7 & 34.7 \\
\hline
\end{tabular}

* Value to an entire column.

The data presented in Table 3 aimed to set up a formulation of polyurethane foams allowing to reduce the demolding time, this formulation and modifications are of industrial relevance and thus to be in accordance with legislative requirements and environmental constraints. As well as to prepare foams 
thermally stable over time and which have homogeneous dispersive properties (chemical structures, density, viscosity) to be used in the formulation of thermal insulation.

\section{Results And Discussion}

In this part, we will be interested in the experimental methodology used to study the influence of the polymerization reactivity of rigid polyurethane foam (ratio, density, reaction temperature and foam rise) and the different properties of dispersive foam. The foam is formed from an exothermic reaction for few minutes. The hydrocarbon blowing agents (HBAs) used in this study are generally inert liquids with low boiling point characteristics. Note that 5 carbon atoms are liquid under normal conditions and are flammable. During the foaming process, a phase change from liquid to rigid foam is obtained, which is followed by a considerable expansion of the foam caused by the effect of the addition of the HBA.

\section{RPUF analysis}

It is difficult to find a typical formulation because of the influence of several factors influencing the morphology of rigid foam as it appears in Fig. 2. Therefore, to find a very efficient formulation, we have grouped various parameters in Fig. 2, such as cream time, gel time, tack-free time, maximum temperature, free-rise density, shrinkage, thermal conductivity.

The charge distribution in the polymer matrix of the foam is controlled by measuring the density at different positions on the mold. Therefore, the density is affected by the added amount of HBA. Serval studies, for example [28-32], have been investigated the influence of the concentration of blowing agents on foam morphology and dimensional stability using different polyurethane formulations. The exothermic reaction between polyol and isocyanate results in a high molecular weight and cross-linked density of polymer whose terminal groups depend on the molar ratio of the reagents used [33,34]. For $n$ hexane at a ratio equal to 1.34 with $12 \% \mathrm{HBA}$, it is observed that the temperature of the polymerization reaction of RPUF can increase to a maximum value of $141.8^{\circ} \mathrm{C}$ in a period of $530 \mathrm{~s}$, and the maximum foam rise height also increases by approximately $268 \mathrm{~mm}$ after $350 \mathrm{~s}$. During $550 \mathrm{~s}$, the temperature of cyclopentane (ratio $=1.25$ and $12 \% \mathrm{HBA}$ ) increases to $139.2^{\circ} \mathrm{C}$ and the foam rise height is stabilized at approximately $273 \mathrm{~mm}$ after $350 \mathrm{~s}$ of polymerization. On the other hand, the thermal conductivity coefficient $(\lambda)$ of pentane derivatives is only a factor of 1.7 , on average, compared to hexane derivatives. Several authors $[2,35]$ show that the ordinary thermal conductivity of an RPUF is between 20 and 45 $\mathrm{mW} / \mathrm{m} . \mathrm{k}$. However, an increase in gel time results in a decrease in foam reactivity, which is the case for $\mathrm{n}$ pentane and $\mathrm{n}$-hexane. We also registered maximum density values for $\mathrm{n}$-hexane and cyclohexane, 34.5 and $38.4 \mathrm{Kg} / \mathrm{m}^{3}$, respectively.

We noticed a high stability of the polyurethane polymerization reaction times in the range of variation of the studied core-rise density $\left(22.9\right.$ to $\left.38.4 \mathrm{Kg} / \mathrm{m}^{3}\right)$. Our findings would seem to show all these results suggest that the ideal ratio (including the percentage of HBA) should be chosen to production of dispersive polyurethane foam using the Reaction-Injection-Molding (RIM) process. 
Fig. 3 shows the variation of free-rise density of the foam as a function of the ration with different percentages of hydrocarbon blowing agents $(12 \%, 13 \%$ and $14 \%)$. When the percentage for each blowing agent is increasing, the foam density decreases for most cases. It was also observed that hexane derivatives give higher density than pentane derivatives. In Fig. 3 for constant percentages of blowing agents, there is a slight variation in density (almost uniform) as a function of different ratios. The RPUF prepared by the blowing agent (12\%) at a ratio equal to 1.25 for a gel time not exceeding 79 seconds, presents a better formulation in terms of shrinkage, dimensional stability foam and insulation.

\section{Thermal proprieties}

The study of thermal properties has given great importance in control the thermal stability of the examined material [36-39]. Fig. 4 shows the variation of the temperature reaction of reaction as a function of the height foam rise. By using five hydrocarbon blowing agents $(12 \%)$ for a ratio of 1.25 , we observe a gradual increase in temperature with time which will increase the reactivity of the foam. The maximum temperature registered between the five blowing agents is that of $n$-hexane $(n-H)$ which can reach $142^{\circ} \mathrm{C}$, which means that the $\mathrm{PU}$ foam prepared from this blowing agent has a high dispersion in the mold. For the blowing agent $n$-hexane, we also observe a rapid change in foam rise for the ratio 1.25 and the height quickly reaches the maximum concerning three blowing agents c-P, i-P and c-H. We can thus confirm that the blowing agent plays a very important role in this stage because its increase results in a relatively high activation energy. It can be assumed that there is an influence of the amount added of the percentage of blowing agents. i.e., the one with a very high height has the lowest boiling temperature.

Thermogravimetry (TGA) and Derivative Thermogravimetric (DTG) are thermal analysis methods that measure the change in mass of a sample as a function of time or temperature in a controlled atmosphere. The instrument used to realize these analyses is known as METTLER TOLEDO STARe SW. Differential Scanning Calorimetry (DSC) is a thermo-analytical technique measuring the amount of energy required to heat a sample as a function of temperature or time, and relative to a reference. The RPUF samples are prepared by using five hydrocarbon blowing agents (HBAs) and tested by using DSC device 131 evo SETARAM.

All analyses are carried out under inert nitrogen to avoid any reaction of the material in the furnace. The temperature range of the experiment is between 0 and $600^{\circ} \mathrm{C}$, with heating and cooling rate of $10^{\circ} \mathrm{C} / \mathrm{min}$. The results obtained by simultaneous analysis of TGA, DTG and DSC application curves on RPUFs prepared with different blowing agents are shown in Fig. 5. These samples represented by the DSC curves indicate that there is crystal melting defined by the peak temperature in the range of 250 to $280^{\circ} \mathrm{C}$. These samples decompose between 220 and $230^{\circ} \mathrm{C}$, the exothermic decomposition peak of DSC corresponds to the 1st derivative of TGA curve $\left(0.04\right.$ to $\left.0.07 \% /{ }^{\circ} \mathrm{C}\right)$ extrapolated onset temperature. It is also observed that the five graphs vary in the same ways at a constant ratio. However, during thermal degradation, the TGA weight loss curve results from the formation of volatile materials. For various blowing agents, the RPUF degraded at 420 to $480^{\circ} \mathrm{C}$ for 50 per cent weight loss. It can be concluded that foam obtained from the i-P is more fire-resistant. 


\section{Mechanical proprieties}

For the characterization of the mechanical behavior of RPUFs under external forces that generate stresses and strains, several mechanical tests are used to evaluate the different HBAs.

This test consists of compressing the sample to $100 \%$ of its initial thickness $(30 \mathrm{~mm})$ at a speed of 5 $\mathrm{mm} / \mathrm{min}$ at $25^{\circ} \mathrm{C}$. A stress, applied to deform the foam samples, is measured by a $2 \mathrm{~N} / \mathrm{mm}$ force sensor and the compression is maintained for 120 seconds using MTS machine. The stress-compression curve is defined as compressive strength it is a function of density and the ability of phase change materials [40]. As it can be seen in Table 4, the most important compression characteristics of polyurethane foam with different HBAs.

Table 4. Foam compression characteristics with different HBAs.

\begin{tabular}{lccccc}
\hline FOAM-DIMENSIONS & Width & Length & & Height \\
Specifications (mm) & 30 & & 30 & & 30 \\
Ratio=1.25 & & & & & \\
HBA=12\% & & & & & \\
\hline Stress-strain characteristics & $\mathrm{n}-\mathrm{P}$ & $\mathrm{i}-\mathrm{P}$ & $\mathrm{c}-\mathrm{P}$ & $\mathrm{n}-\mathrm{H}$ & $\mathrm{c}-\mathrm{H}$ \\
Maximum force (kN) & 0.858 & 0.786 & 0.896 & 0.739 & 0.876 \\
Maximum compressive strain (\%) & 85.829 & 85.951 & 85.422 & 63.338 & 63.561 \\
Peak stress (MPa) & 0.953 & 0.873 & 0.996 & 0.821 & 0.973 \\
\hline
\end{tabular}

The characteristic curves shown in the deformation tests of RPUF samples of different HBAs are presented in Fig. 6 (a). These curves show three regions: (i) A linear elastic phase of small deformations (up to $5 \%$ ) this confirms that the foam prepared does not contain any elasticity. (ii) As the load increases, the cell walls begin to collapse and progress at an approximately constant load, giving a stress level the region where the stress does not increase significantly with the increase in percentage compression characterized by a line roughly parallel to the compression strain axis. (iii) A further increase in load leads to densification of the collapsed cell walls, which causes a rapid increase in stress without a significant rise in tension.

When comparing between the two series of blowing agents used in the formulation of RPUF, we notice that the compressive percentage of foam prepared by pentane derivatives is more resistant compared to hexane derivatives. Note that the foam prepared by the blowing agent cyclohexane has a high peak stress compressive. Fig. 6 (b) shows the shrinkage and the maximum compressive strength results as a function of density for the prepared foams with five hydrocarbon blowing agents. It can also be seen that all samples have a shrinkage does not exceed an overall deformation of $2.5 \%$. 


\section{Conclusion}

This paper has given an account of improving the chemical formulation of rigid polyurethane foam (RPUF) in the presence of two series of hydrocarbon blowing agents (HBAs), pentane derivatives and hexane derivatives, to obtain a stable and durable polymer. According to the results obtained, it is noted that hexane derivatives are used principally as an alternative with HBAs such as n-pentane, isopentane and cyclopentane. It provides RPUF with good strength (uniform density and good dimensional stability) and considerable reactivity with a highly exothermic polymerization reaction compared to the use of other blowing agents, which can reach about $142^{\circ} \mathrm{C}$. However, the thermal insulation of the foam is somewhat moderate.

In terms of reactivity of the reaction (gel time), we found that the blowing agent $\mathrm{c}-\mathrm{H}$ is more reactive than the blowing agent n-P. The values for the foam rise height (the homogeneous dispersion of PU foam) increase faster with c-H than with n-P. This confirms that hexane derivatives have a high expansion rate, i.e. they are more dispersive. The density of the finished product must be moderate, and it also has a low thermal conductivity insulation.

\section{Declarations}

\section{Acknowledgements}

This work was supported by the general direction of scientific research and technological development (DGRSDT), Ministry of high education and scientific research, Algeria.

\section{References}

[1] Zhang H, Fang WZ, Li YM, Tao WQ (2017) Therm Eng 115: 528-538

https://doi.org/10.1016/j.applthermaleng.2016.12.057

[2] Dohrn R, Fonseca JM, Albers R, Kušan-Bindels J, Marrucho IM (2007) Fluid Phase Equilib 261: 4149 https://doi.org/10.1016/j.fluid.2007.07.059

[3] Jelle BP (2011) Energy Build 43: 2549-2563 https://doi.org/10.1016/j.enbuild.2011.05.015

[4] Szycher M (2012) Szycher's handbook of polyurethanes: Second edition. CRC Press, New York https://doi.org/10.1201/b12343

[5] Carriço CS, Fraga T, Carvalho VE, Pasa VMD (2017) Molecules 22(7) :1091

https://doi.org/10.3390/molecules22071091

[6] Jin FL, Zhao M, Park M, Park SJ (2019) Polymers (Basel) 11: 1-24

https://doi.org/10.3390/polym11060953. 
[7] Ashida K (2006) Polyurethane and Related Foams Chemistry and Technology.Taylor \& F, CRC Press, New York https://doi.org/10.1201/9780203505991

[8] Al-Moameri HH, Nabhan BJ, Tawfeeq Wasmi M, Abdulrehman MA (2020) AIP Conf Proc 2213 https://doi.org/10.1063/5.0000153

[9] Furtwengler P, Perrin R, Redl A, Avérous L (2017) Eur Polym J 97 : 319-327

https://doi.org/10.1016/j.eurpolymj.2017.10.020

[10] Gómez-Fernández S, Ugarte L, Peña-Rodriguez C, Zubitur M, Corcuera MÁ (2016) Appl Clay Sci 123: 109-120 https://doi.org/10.1016/j.clay.2016.01.015

[11] Choe KH, Soo DL, Seo WJ, Kim WN (2004) Polym J 36: 368-373 https://doi.org/10.1295/polymj.36.368

[12] S.N. Singh (2002) Blowing Agents for Polyurethanes foams. Rapra Technology Limited, Shawbury

[13] Karimi DL, Marchisio M (2015) Macromol Theory Simulations 24: 291-300 https://doi.org/10.1002/mats.201500014

[14] Zhang D, Zhang G, Wu Q, Zhang Y, Cao H, Han J (2017) J Appl Polym Sci 134: 45582 https://doi.org/10.1002/app.45582

[15] Wallington TJ, Sulbaek Andersen MP, Nielsen OJ (2010) Atmos Environ 44:1478-1481 https://doi.org/10.1016/j.atmosenv.2010.01.040

[16] Berardi U, Madzarevic J (2020) Appl Therm Eng 164

https://doi.org/10.1016/j.applthermaleng.2019.114440

[17] Jelle BP, Jin FL, Zhao M et al (2020) Appl Therm Eng 105: 201-210 https://doi.org/10.1016/j.applthermaleng.2019.114440

[18] Al-Moameri H, Zhao Y, Ghoreishi R, Suppes GJ (2015) J Appl Polym Sci 132: 1-7 https://doi.org/10.1002/app.42454

[19] Jang S, Kim S (2016) J Korean Inst Gas 20: 30-34 https://doi.org/10.7842/kigas.2016.20.2.30

[20] Baasandorj M, Ravishankara AR, Burkholder JB (2011) J Phys Chem A 115: 10539-10549 https://doi.org/10.1021/jp206195g

[21] Bansal P, Vineyard E, Abdelaziz O (2011) Appl Therm Eng 3748-3760 https://doi.org/10.1016/j.applthermaleng.2011.07.023

[22] Marrucho IM, Santos F, Oliveira NS, Dohrn R (2005) J Cell Plast 41: 207-224 https://doi.org/10.1177/0021955X05053520 
[23] Baasandorj M, Ravishankara AR, Burkholder JB (2011) J Phys Chem A 115: 10539-10549 https://doi.org/10.1021/jp206195g

[24] Loh G, Ata SA, Jovicic J (2015) Recent Development of Formacel $₫ 1100$ - a Zero ODP and Low GWP Foam Expansion Agent

[25] Gómez-Fernández S, Günther M, Schartel B, Corcuera MA, Eceiza A (2018) Ind Crops Prod 125: 346359 https://doi.org/10.1016/j.indcrop.2018.09.018

[26] Seidel S, Ye J, Andersen SO, Hillbrand A (2016) Cent Clim Energy Solut 27 https://www.c2es.org

[27] Bakiri Z, Nacef S (2017) Russ J Appl Chem 90(3): 474-479

https://doi.org/10.1134/S1070427217030223

[28] Matson SM, Zhilyaeva NA, Bakirov AV, Chvalun SN, VS Khotimskiy (2021) Polym J 53: 449-454 https://doi.org/10.1038/s41428-020-00437-z

[29] Andersson A, Magnusson A, Troedsson S, Lundmark S, Maurer FHJ (2008) J Appl Polym Sci 109: 2269-2274 https://doi.org/10.1002/app.28282

[30] Koutian A, Assaela MJ, Huber ML, Perkins RA (2017) J Phys Chem Ref Data 46 https://doi.org/10.1063/1.4974325

[31] Al-Moameri H, Zhao Y, Ghoreishi R, Suppes GJ (2016) Ind Eng Chem Res 55: 2336-2344 https://doi.org/10.1021/acs.iecr.5b04711

[32] Członka S, Strakowska A, Strzelec K, Adamus-Włodarczyk A, Kairyte A, Vaitkus S (2019) Polymers (Basel) 11 https://doi.org/10.3390/polym11020336

[33] Stirna U, Beverte I, Yakushin V, Cabulis U (2011) J Cell Plast 47: 337-355 https://doi.org/10.1177/0021955X11398381

[34] Engels HW, Pirkl HG, Albers R, Albach RW, Krause J, Hoffmann A, Casselmann H, Dormish J (2013) Angew Chemie - Int Ed 52: 9422-9441 https://doi.org/10.1002/anie.201302766

[35] Li B, Yuan Z, Schmidt J, Xu C (2019) Eur Polym J 111: 1-10 https://doi.org/10.1016/j.eurpolymj.2018.12.011

[36] Dhaliwal GS, Anandan S, Chandrashekhara K, Dudenhoeffer N, Nam P (2019) J Polym Environ 27: 1897-1907 https://doi.org/10.1007/s10924-019-01477-0

[37] Jing J, Song L, Su T, Wang Z (2020) Polym Eng Sci 1-9 https://doi.org/10.1002/pen.25581

[38] Wang S, Liu W, Yang D, Qiu X (2019) Ind Eng Chem Res 58: 496-504 https://doi.org/10.1021/acs.iecr.8b05072 
[39] Chiu HT, Yang HM, Liu CS (2014) Polymer Science Ser B 56(2): 247-256

https://doi.org/10.1134/S1560090414020043

[40] Berrier RE, Singh SN, Costa JS, Bonapersona V (1999) J Cell Plast 35: 311-327 https://doi.org/10.1177/0021955X9903500403

\section{Figures}

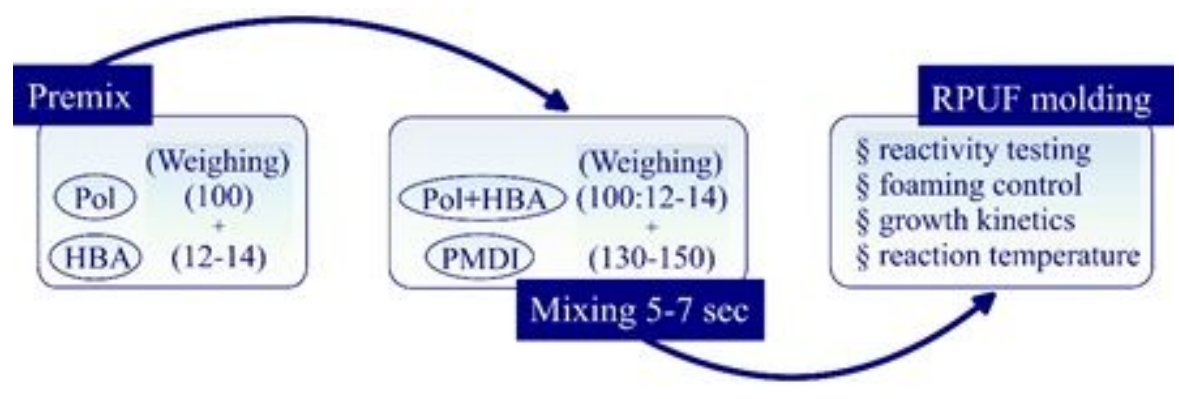

\section{Figure 1}

Rigid polyurethane foam preparation and process control

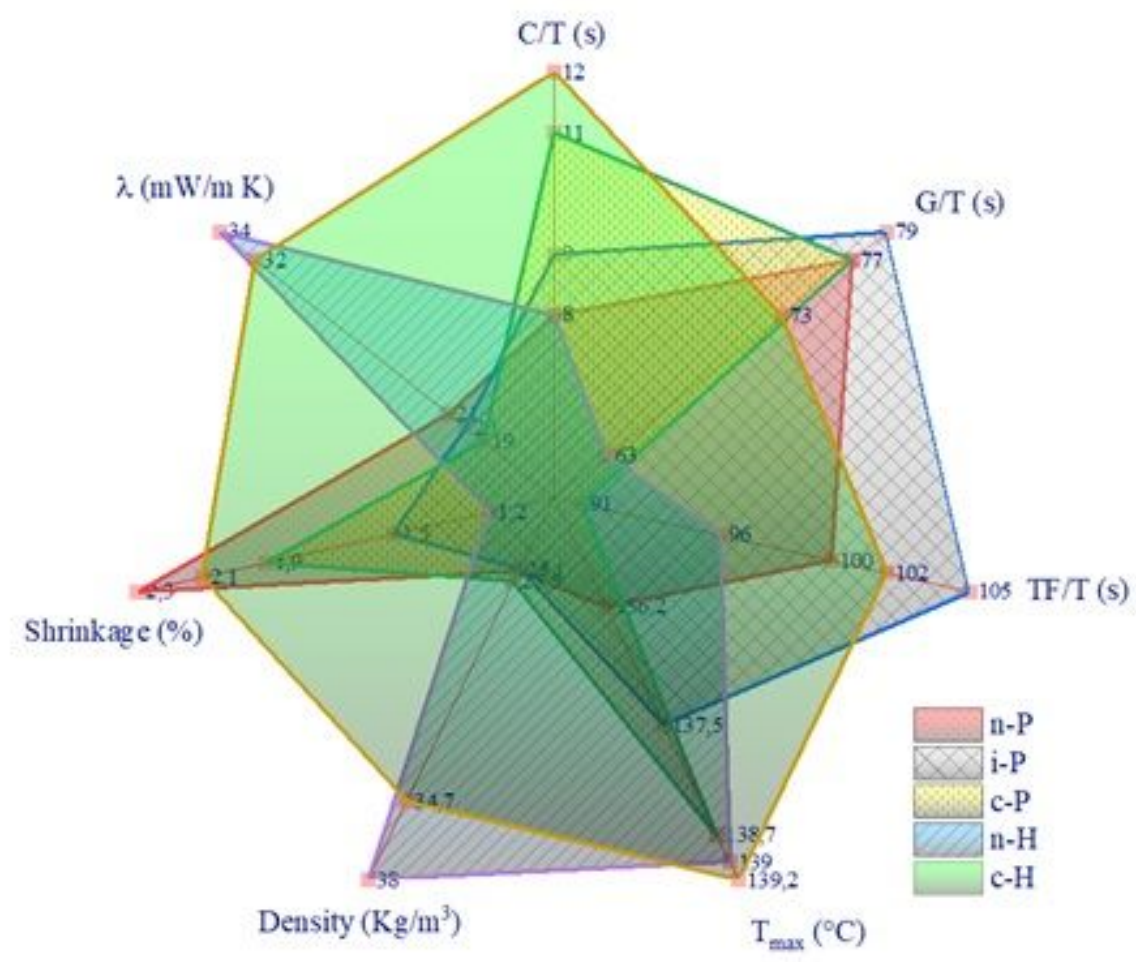

\section{Figure 2}

Influence of the performance parameters of the RPUF with different HBAs 


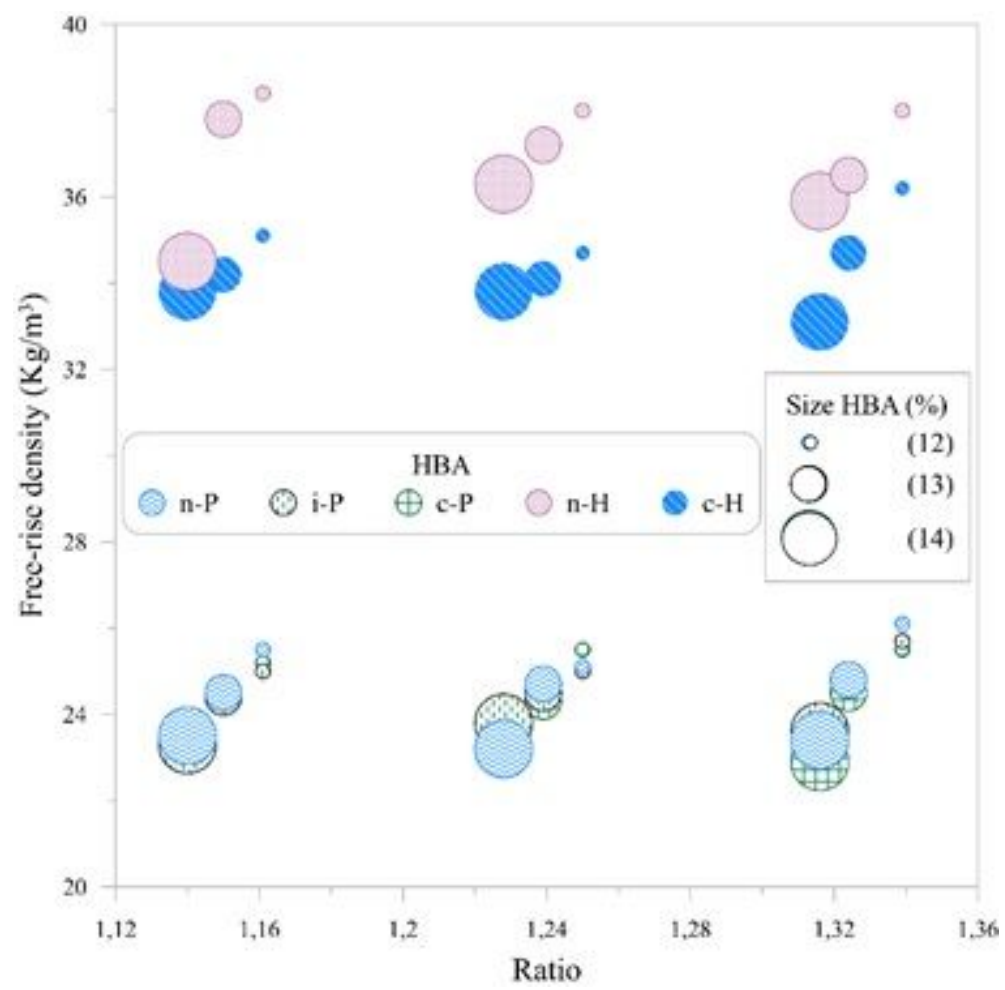

Figure 3

Effect of free-rise density on the ratio for different percentages of HBA

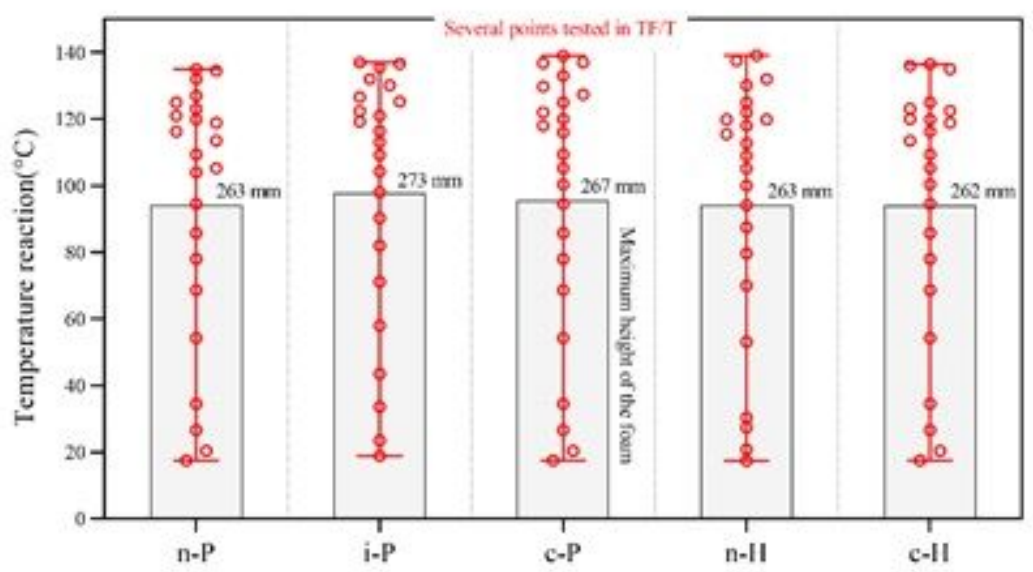

Figure 4

Temperature reaction and height of RPUF for different HBAs (ratio=1.25 and 12\% HBA) 


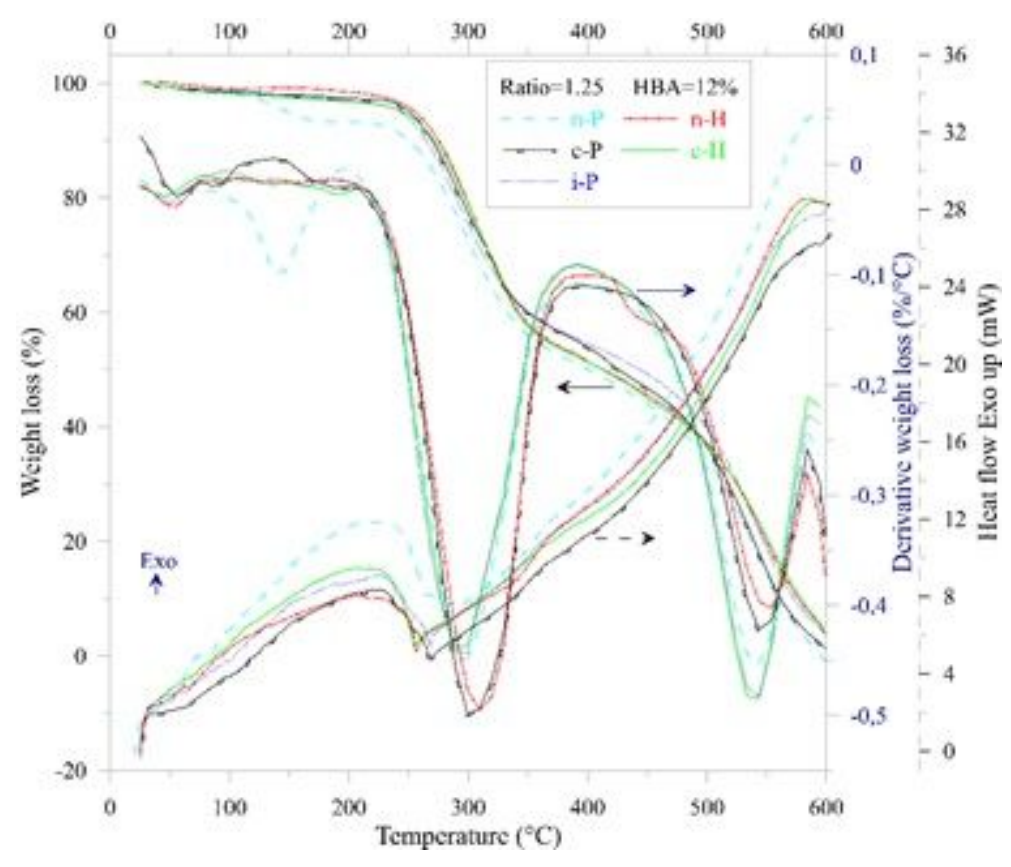

Figure 5

TGA, DTG and DSC results of RPUFs
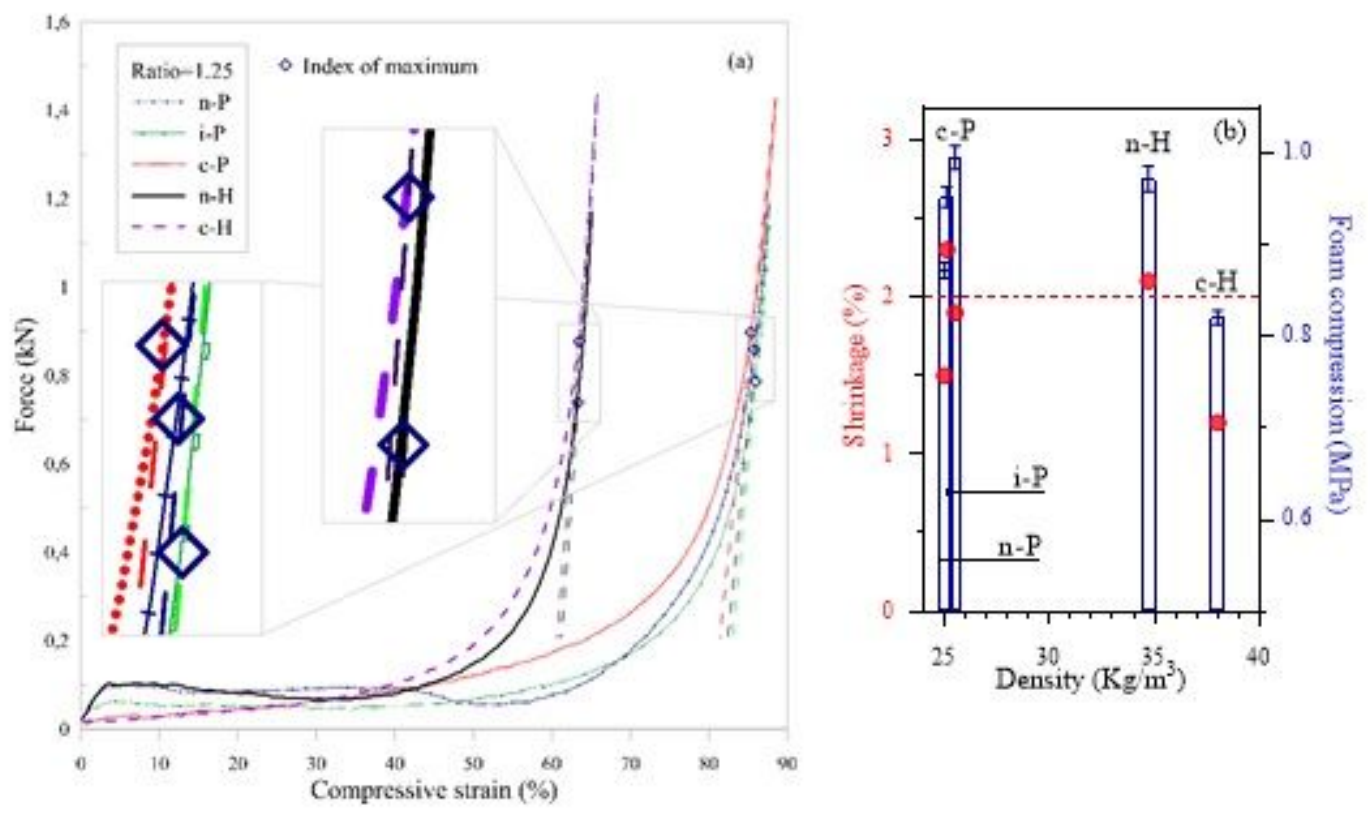

Figure 6

Mechanical proprieties of the foam samples: (a) effect of HBAs on the stress-compression, (b) relation between shrinkage and foam compression as a function of density 